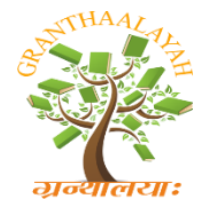

INTERNATIONAL JOURNAL OF RESEARCH GRANTHAALAYAH A knowledge Repository

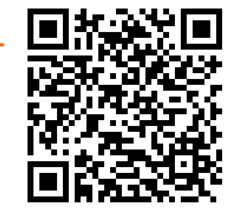

Social

\title{
A STUDY OF MULTIPLE INTELLIGENCE IN RELATING TO LEARNING STYLE AMONG HIGHER SECONDARY STUDENTS
}

\author{
Jeevitha.S ${ }^{* 1}$, Mrs.Vanitha.J ${ }^{2}$ \\ ${ }^{* 1}$ MEd Scholar, RVS College of Education, India \\ ${ }^{2}$ Assistant Professor in Physics Education, RVS College of Education, India
}

DOI: https://doi.org/10.29121/granthaalayah.v5.i6.2017.2031

\begin{abstract}
Students' reveal different learning styles and multiple intelligences, and only by accommodating these several abilities can teachers appropriately plan and conduct tasks and evaluate what students have learned. The present study describes the types of learning styles and multiple intelligences of students, as well as instructional methods that work best with students' relevant learning traits. The main motive is to study on multiple intelligence in relating to learning style among higher secondary students in Coimbatore district. This research is under taken with a view to examining the relationship with multiple intelligence and learning style of different high school students with a sample size 300 . The investigation is analyzed by the descriptive analysis and differential analysis. The result concluded from the study that there is no substantial change with respect to gender, locality, groups and board of institution in their mean score of multiple intelligence and learning style. The correlation is not significant with the multiple intelligence and learning style.
\end{abstract}

Keywords: Multiple Intelligence; Learning Style; Academic.

Cite This Article: Jeevitha.S, and Mrs.Vanitha.J. (2017). "A STUDY OF MULTIPLE INTELLIGENCE IN RELATING TO LEARNING STYLE AMONG HIGHER SECONDARY STUDENTS." International Journal of Research - Granthaalayah, 5(6), 310-319. https://doi.org/10.29121/granthaalayah.v5.i6.2017.2031.

\section{Introduction}

Learning styles and multiple intelligences have been examined in the last periods as important variables that impact the learning procedures among students. The present study hypothesizes that there will be a strong relationship between learning styles and their consistent multiple intelligences among higher secondary school students. This study aims to find counterparts between the two concepts, learning styles and multiple intelligences. While trying to comprehend individual differences during the learning process, it became clear that evidence about general intelligence and personality give only a partial explanation. Learning styles and multiple 
intelligences contribute to a better understanding of the difference between individuals among the higher secondary school students in their process of learning.

\subsection{Objectives of the Study}

There are two main types of objectives undertaken by the investigator in this study work.

\subsubsection{General Objectives}

- To study the multiple intelligence in relating to learning style among higher secondary students in Coimbatore district.

- To adopt questionnaire on multiple intelligence and learning style among higher secondary school students.

\subsubsection{Specific Objectives}

- To find out the multiple intelligence among higher secondary school students.

- To find out the learning style among higher secondary school students.

- To find out the impact of personal variables like Gender, Locality, Groups and Board of school among higher secondary school students.

\section{Research Design}

The investigator adopted survey method to study on multiple intelligence and its impact on their academic achievement in Coimbatore district. For this study a sample of 300 from 5 various schools which are situated in and around Coimbatore district in Tamilnadu were selected by the investigator using simple random sampling technique.

Table 1: Distribution of Samples based on Variables

\begin{tabular}{|c|c|c|c|c|c|}
\hline S.NO & Category & Subgroups & Number & $\%$ & Tota \\
\hline \multirow[b]{2}{*}{1.} & \multirow[b]{2}{*}{ Gender } & Male & 152 & $50.7 \%$ & \multirow[t]{2}{*}{300} \\
\hline & & Female & 148 & $49.3 \%$ & \\
\hline \multirow[b]{2}{*}{2.} & \multirow[b]{2}{*}{ Locality } & Rural & 134 & $44.7 \%$ & \multirow[t]{2}{*}{300} \\
\hline & & Urban & 166 & $55.3 \%$ & \\
\hline \multirow[b]{2}{*}{3.} & \multirow[t]{2}{*}{ Groups } & Science Group & 139 & $46.3 \%$ & \multirow[t]{2}{*}{300} \\
\hline & & Arts Group & 161 & $53.7 \%$ & \\
\hline \multirow[t]{3}{*}{4.} & \multirow[t]{3}{*}{ Board of Institution } & Government & 50 & $16.7 \%$ & \multirow[t]{3}{*}{300} \\
\hline & & Aided & 80 & $26.7 \%$ & \\
\hline & & Metric & 170 & $56.7 \%$ & \\
\hline
\end{tabular}

\subsection{Scoring Procedure}

The collected responses were scored with the help of the Yes or No scale scoring key. Scoring for the positive items follows a system of 2 to 1 from left to right. There are no negative items in the scale. Accordinly, 30 is the maximum score and 15 is the minimum score for the multiple intelligence. More score indicates high in multiple intelligence and fewer score indicates low in 
multiple intelligence. Similarly, 30 is the maximum score and 15 is the minimum score for the learning style. More score indicates high in learning style and fewer score indicates low in learning style.

Table 2: Scoring Procedure for Learning Style

\begin{tabular}{|l|l|l|}
\hline S.No & Rank & Score \\
\hline 1. & Low & $15-20$ \\
\hline 2. & Moderate & $21-25$ \\
\hline 3. & High & $26-30$ \\
\hline
\end{tabular}

Table 3: Scoring Procedure for Multiple Intelligence

\begin{tabular}{|l|l|l|}
\hline S.No & Rank & Score \\
\hline 1. & Low & $15-20$ \\
\hline 2. & Moderate & $21-25$ \\
\hline 3. & High & $26-30$ \\
\hline
\end{tabular}

HYPOTHESIS 1: There will be a significant mean score difference in the level of learning style among higher secondary students with respect to Gender.

Table 4: Significant mean score difference in the level of learning style among higher secondary students with respect to Gender.

\begin{tabular}{|l|l|l|l|l|l|l|l|l|}
\hline Variable & Gender & Low & \multicolumn{2}{|l|}{ Moderate } & High & \multirow{2}{*}{} \\
\cline { 3 - 10 } & & $\mathbf{N}$ & $\mathbf{\%}$ & $\mathbf{N}$ & $\mathbf{\%}$ & $\mathbf{N}$ & $\mathbf{\%}$ & Total \\
\hline $\begin{array}{l}\text { Learning } \\
\text { Style }\end{array}$ & Male & 89 & 58.55 & 62 & 40.79 & 1 & 0.66 & 152 \\
\cline { 2 - 10 } & Female & 92 & 62.16 & 56 & 37.84 & 0 & 0 & 148 \\
\hline
\end{tabular}

Table 4 exhibits the result of the level of learning style among higher secondary students with respect to Gender. According to the table that amid the male students, $0.66 \%$ of them have high level of learning style, $40.79 \%$ of them have moderate level of learning style and $58.55 \%$ of them have low level of learning style. Likewise, amid the female students, $37.84 \%$ of them have moderate level of learning style and $62.16 \%$ of them have low level of learning style.

HYPOTHESIS 2: There will be a significant mean score difference in the level of multiple intelligence among higher secondary students to Gender.

Table 5: Significant mean score difference in the level of multiple intelligence among higher secondary students to Gender.

\begin{tabular}{|c|c|c|c|c|c|c|c|c|}
\hline \multirow[t]{2}{*}{ Variable } & \multirow[t]{2}{*}{ Gender } & \multicolumn{2}{|c|}{ Low } & \multicolumn{2}{|c|}{ Moderate } & \multicolumn{2}{|c|}{ High } & \multirow[b]{2}{*}{ Total } \\
\hline & & $\mathbf{N}$ & $\%$ & $\mathbf{N}$ & $\%$ & $\mathbf{N}$ & $\%$ & \\
\hline \multirow{2}{*}{$\begin{array}{l}\text { Multiple } \\
\text { Intelligence }\end{array}$} & Male & 2 & 1.32 & 97 & 63.82 & 53 & 34.87 & 152 \\
\hline & Female & 2 & 1.35 & 77 & 52.03 & 69 & 46.62 & 148 \\
\hline
\end{tabular}


Table 5 exhibits the result of the level of multiple intelligence among higher secondary students with respect to Gender. According to the table that amid the male students, $34.87 \%$ of them have high level of multiple intelligence, $63.82 \%$ of them have moderate level of multiple intelligence and $1.32 \%$ of them have low level of multiple intelligence. Likewise, amid the female students, $46.62 \%$ of them high level, $52.03 \%$ of them have moderate level and $1.35 \%$ of them have low level.

HYPOTHESIS 3: There will be a significant mean score difference in the level of learning style among higher secondary students with respect to locality.

Table 6: Significant mean score difference in the level of learning style among higher secondary students with respect to locality.

\begin{tabular}{|c|c|c|c|c|c|c|c|c|}
\hline \multirow[t]{2}{*}{ Variable } & \multirow[t]{2}{*}{ Locality } & \multicolumn{2}{|c|}{ Low } & \multicolumn{2}{|c|}{ Moderate } & \multicolumn{2}{|c|}{ High } & \multirow[b]{2}{*}{ Total } \\
\hline & & $\mathbf{N}$ & $\%$ & $\mathbf{N}$ & $\%$ & $\mathbf{N}$ & $\%$ & \\
\hline \multirow{2}{*}{$\begin{array}{l}\text { Learning } \\
\text { Style }\end{array}$} & Rural & 81 & 60.45 & 53 & 39.55 & 0 & 0 & 134 \\
\hline & Urban & 100 & 60.24 & 65 & 39.16 & 1 & 0.60 & 166 \\
\hline
\end{tabular}

Table 6 exhibits the result of the level of learning style among higher secondary students with respect to locality. According to the table that amid the rural students, $60.45 \%$ of them have high level of learning style and $39.55 \%$ of them have moderate level of learning style. Likewise, amid the urban students, $60.24 \%$ of them high level, $39.16 \%$ of them have moderate level and $0.60 \%$ of them have low level.

HYPOTHESIS 4: There will be a significant mean score difference in the level of multiple intelligence among higher secondary students with respect to locality.

Table 7: Significant mean score difference in the level of multiple intelligence among higher secondary students with respect to locality.

\begin{tabular}{|l|l|l|l|l|l|l|l|l|}
\hline Variable & Locality & Low & \multicolumn{4}{l|}{ Moderate } & High & \multirow{2}{*}{ Total } \\
\cline { 3 - 10 } & & $\mathbf{N}$ & $\mathbf{\%}$ & $\mathbf{N}$ & $\mathbf{\%}$ & $\mathbf{N}$ & $\mathbf{\%}$ & 134 \\
\hline $\begin{array}{l}\text { Multiple } \\
\text { Intelligence }\end{array}$ & Rural & 1 & 0.75 & 82 & 61.19 & 51 & 38.06 & 134 \\
\cline { 2 - 10 } & Urban & 3 & 1.80 & 92 & 55.42 & 71 & 42.77 & 166 \\
\hline
\end{tabular}

Table 7 exhibits the result of the level of multiple intelligence among higher secondary students with respect to locality. According to the table that amid the rural students, $38.06 \%$ of them have high level of multiple intelligence, $61.19 \%$ of them have moderate level of multiple intelligence and $0.75 \%$ of them have low level of multiple intelligence. Likewise, amid the urban students, $42.77 \%$ of them high level, $55.42 \%$ of them have moderate level and $1.80 \%$ of them have low level.

HYPOTHESIS 5: There will be a significant mean score difference in the level of learning style among higher secondary students with respect to groups. 
Table 8: Significant mean score difference in the level of learning style among higher secondary students with respect to groups.

\begin{tabular}{|l|l|l|l|l|l|l|l|l|}
\hline Variable & \multirow{6}{*}{ Group } & Low & Moderate & High & \multirow{2}{*}{ Total } \\
\cline { 3 - 10 } & & $\mathbf{N}$ & $\mathbf{\%}$ & $\mathbf{N}$ & $\mathbf{\%}$ & $\mathbf{N}$ & $\mathbf{\%}$ & 139 \\
\hline \multirow{2}{*}{$\begin{array}{l}\text { Learning } \\
\text { Style }\end{array}$} & Science & 76 & 54.68 & 63 & 45.32 & 0 & 0 & 161 \\
\cline { 2 - 10 } & Arts & 105 & 65.22 & 55 & 34.16 & 1 & 0.62 & \\
\hline
\end{tabular}

Table 8 exhibits the result of the level of learning style among higher secondary students with respect to groups. According to the table that amid the science students, $45.32 \%$ of them have moderate level of learning style and $54.68 \%$ of them have low level of learning style. Likewise, amid the arts students, $0.62 \%$ of them have high level, $34.16 \%$ of them have moderate level and $65.22 \%$ of them have low level.

HYPOTHESIS 6: There will be a significant mean score difference in the level of multiple intelligence among higher secondary students with respect to groups.

Table 9: Significant mean score difference in the level of multiple intelligence among higher secondary students with respect to groups.

\begin{tabular}{|l|l|l|l|l|l|l|l|l|}
\hline Variable & \multirow{2}{*}{ Group } & Low & \multicolumn{4}{l|}{ Moderate } & High & \multirow{2}{*}{ Total } \\
\cline { 3 - 10 } & & $\mathbf{N}$ & $\mathbf{\%}$ & $\mathbf{N}$ & $\mathbf{\%}$ & $\mathbf{N}$ & $\mathbf{\%}$ & 139 \\
\hline $\begin{array}{l}\text { Multiple } \\
\text { Intelligence }\end{array}$ & Science & 0 & 0 & 91 & 65.47 & 48 & 34.53 & 139 \\
\cline { 2 - 10 } & Arts & 4 & 2.48 & 83 & 51.55 & 74 & 45.96 & 161 \\
\hline
\end{tabular}

Table 9 exhibits the result of the level of multiple intelligence among higher secondary students with respect to groups. According to the table that amid the science students, $34.53 \%$ of them have high level and $65.47 \%$ of them have moderate level of multiple intelligence. Likewise, amid the arts students, $45.96 \%$ of them have high level, $51.55 \%$ of them have moderate level and $2.48 \%$ of them have low level.

HYPOTHESIS 7: There will be a significant mean score difference in the level of learning style among higher secondary students with respect to board of institution.

Table 10: Significant mean score difference in the level of learning style among higher secondary students with respect to board of institution.

\begin{tabular}{|c|c|c|c|c|c|c|c|c|}
\hline \multirow[t]{2}{*}{ Variable } & \multicolumn{3}{|c|}{ Board of Low } & \multicolumn{2}{|c|}{ Moderate } & \multicolumn{2}{|c|}{ High } & \multirow[b]{2}{*}{ Total } \\
\hline & Institution & $\mathbf{N}$ & $\%$ & $\mathbf{N}$ & $\%$ & $\mathbf{N}$ & $\%$ & \\
\hline \multirow{3}{*}{$\begin{array}{l}\text { Learning } \\
\text { Style }\end{array}$} & Govt & 0 & 0 & 29 & 58 & 21 & 42 & 50 \\
\hline & Aided & 0 & 0 & 59 & 73.75 & 21 & 26.25 & 80 \\
\hline & Metric & 4 & 2.35 & 90 & 52.94 & 76 & 44.71 & 170 \\
\hline
\end{tabular}

Table 10 exhibits the result of the level of learning style among higher secondary students with respect to board of institution. According to the table that amid the Government students, $42 \%$ of them have high level and $58 \%$ of them have moderate level of learning style. Amid the Aided 
school students, $26.25 \%$ of them have high level and $73.75 \%$ of them have moderate level. Amid the metric students, $44.71 \%$ of them have high level, $52.94 \%$ of them have moderate level and $2.35 \%$ of them have low level of learning style.

HYPOTHESIS 8: There will be a significant mean score difference in the level of multiple intelligence among higher secondary students with respect to board of institution.

Table 11: Significant mean score difference in the level of multiple intelligence among higher secondary students with respect to board of institution.

\begin{tabular}{|l|l|l|l|l|l|l|l|l|}
\hline \multirow{2}{*}{ Variable } & \multirow{3}{*}{$\begin{array}{l}\text { Board of } \\
\text { Institution }\end{array}$} & Low & Moderate & High & \multirow{2}{*}{ Total } \\
\cline { 2 - 9 } & $\mathbf{N}$ & $\mathbf{\%}$ & $\mathbf{N}$ & $\mathbf{\%}$ & $\mathbf{N}$ & $\%$ & 50 \\
\hline \multirow{2}{*}{$\begin{array}{l}\text { Multiple } \\
\text { intelligence }\end{array}$} & Govt & 0 & 0 & 18 & 36 & 32 & 64 & 50 \\
\cline { 2 - 9 } & Aided & 1 & 1.25 & 63 & 78.75 & 16 & 20 & 80 \\
\cline { 2 - 8 } & Metric & 3 & 1.76 & 93 & 54.71 & 74 & 43.53 & 170 \\
\hline
\end{tabular}

Table 11 exhibits the result of the level of multiple intelligence among higher secondary students with respect to board of institution. According to the table that amid the Government students, $64 \%$ of them have high level and $36 \%$ of them have moderate level of multiple intelligence. Amid the Aided school students, $20 \%$ of them have high level,78.75\% of them have moderate level and $1.25 \%$ of them have low level of multiple intelligence. Amid the metric students, $43.53 \%$ of them have high level, $54.71 \%$ of them have moderate level and $1.76 \%$ of them have low level of multiple intelligence.

HYPOTHESIS 9: There will be a significant relationship between multiple intelligence and learning style among higher secondary students with respect to gender

Table 12: ' $t$ ' value between multiple intelligence and learning style among higher secondary students with respect to gender

\begin{tabular}{|c|c|c|c|c|c|c|}
\hline Variable & Gender & Number & Mean & S.D & t value & Remarks \\
\hline Multiple & Male & 152 & 1.349 & 0.09 & \multirow[b]{2}{*}{0.88} & \multirow{2}{*}{$\begin{array}{l}\text { Not } \\
\text { significant }\end{array}$} \\
\hline $\begin{array}{l}\text { Intelligence \& } \\
\text { Learning Style }\end{array}$ & Female & 148 & 1.345 & 0.10 & & \\
\hline
\end{tabular}

(at 0.05 significant level the table value of ' $t$ ' is 1.98)

\section{Inference}

Since the calculated value $(0.88)$ is less than the table value of ' $t$ ' (1.98), the null hypothesis is accepted. It is inferred from the above table that there is no significant relationship between multiple intelligence and learning style among higher secondary students with respect to gender.

HYPOTHESIS 10: There will be a significant relationship between multiple intelligence and learning style among higher secondary students with respect to locality 
Table 13: ' $t$ ' value between multiple intelligence and learning style among higher secondary students with respect to locality.

\begin{tabular}{|l|l|l|l|l|l|l|}
\hline Variable & Locality & Number & Mean & S.D & t value & Remarks \\
\hline $\begin{array}{l}\text { Multiple } \\
\begin{array}{l}\text { Intelligence } \\
\text { Learning Style }\end{array}\end{array}$ & Rural & 134 & 1.36 & 0.14 & & $\begin{array}{l}\text { Not } \\
\text { significant }\end{array}$ \\
\cline { 2 - 5 } & Urban & 166 & 1.34 & 0.08 & 0.52 & \\
\hline
\end{tabular}

(at 0.05 significant level the table value of ' $t$ ' is 1.98)

\section{Inference}

Since the calculated value (0.52) is less than the table value of ' $t$ ' (1.98), the null hypothesis is accepted. It is inferred from the above table that there is no significant relationship between multiple intelligence and learning style among higher secondary students with respect to locality.

HYPOTHESIS 11: There will be a significant relationship between multiple intelligence and learning style among higher secondary students with respect to groups

Table 14: ' $t$ ' value between multiple intelligence and learning style among higher secondary students with respect to groups

\begin{tabular}{|l|l|l|l|l|l|l|}
\hline Variable & Groups & Number & Mean & S.D & t value & Remarks \\
\hline $\begin{array}{l}\text { Multiple } \\
\begin{array}{l}\text { Intelligence } \\
\text { Learning Style }\end{array}\end{array}$ & Science & 139 & 1.38 & 0.18 & & $\begin{array}{l}\text { Not } \\
\text { significant }\end{array}$ \\
\cline { 2 - 5 } & Arts & 161 & 1.32 & 0.08 & 0.14 & \\
\hline
\end{tabular}

(at 0.05 significant level the table value of ' $t$ ' is 1.98)

\section{Inference}

Since the calculated value (0.14) is less than the table value of ' $t$ ' (1.98), the null hypothesis is accepted. It is inferred from the above table that there is no significant relationship between multiple intelligence and learning style among higher secondary students with respect to groups.

HYPOTHESIS 12: There will be a significant difference between multiple intelligence among higher secondary students in relation to gender

Table 15: ' $t$ ' value between multiple intelligence among higher secondary students in relation to gender

\begin{tabular}{|l|l|l|l|l|c|l|}
\hline Variable & Gender & Number & Mean & S.D & t value & Remarks \\
\hline Multiple & Male & 152 & 1.35 & 0.10 & & $\begin{array}{l}\text { Not } \\
\text { Intelligence }\end{array}$ \\
\cline { 2 - 5 } & Female & 148 & 1.34 & 0.11 & 0.92 & significant \\
\hline
\end{tabular}

(at 0.05 significant level the table value of ' $t$ ' is 1.98)

\section{Inference}

Since the calculated value (0.92) is less than the table value of ' $t$ ' (1.98), the null hypothesis is accepted. It is inferred from the above table that there is no significant relationship between multiple intelligence among higher secondary students in relation to gender.

HYPOTHESIS 13: There will be a significant difference between learning style among higher secondary students in relation to gender 
Table 16: ' $t$ ' value between learning style among higher secondary students in relation to gender.

\begin{tabular}{|l|l|l|l|l|c|l|}
\hline Variable & Gender & Number & Mean & S.D & t value & Remarks \\
\cline { 1 - 5 } Learning & Male & 152 & 1.352 & 0.094 & & $\begin{array}{l}\text { Not } \\
\text { Style }\end{array}$ \\
\cline { 2 - 5 } & Female & 148 & 1.348 & 0.093 & 0.918 & signicant \\
\hline
\end{tabular}

(at 0.05 significant level the table value of ' $t$ ' is 1.98 )

\section{Inference}

Since the calculated value (0.918) is less than the table value of ' $t$ ' (1.98), the null hypothesis is accepted. It is inferred from the above table that there is no significant relationship between learning style among higher secondary students in relation to gender.

HYPOTHESIS 14: There will be a significant difference between multiple intelligence bases of the locality among higher secondary students.

Table 17: ' $t$ ' value between multiple intelligence bases of the locality among higher secondary students.

\begin{tabular}{|l|l|l|l|l|c|l|}
\hline Variable & Locality & Number & Mean & S.D & t value & Remarks \\
\hline Multiple & Rural & 134 & 1.35 & 0.16 & & $\begin{array}{l}\text { Not } \\
\text { Intelligence }\end{array}$ \\
\cline { 2 - 5 } & Urban & 166 & 1.34 & 0.08 & 0.59 & significant \\
\hline
\end{tabular}

(at 0.05 significant level the table value of ' $t$ ' is 1.98 )

\section{Inference}

Since the calculated value (0.59) is less than the table value of ' $t$ ' (1.98), the null hypothesis is accepted. It is inferred from the above table that there is no significant difference between multiple intelligence bases of the locality among higher secondary students.

HYPOTHESIS 15: There will be a significant difference between learning style bases of the locality among higher secondary students.

Table 18: ' $t$ ' value between learning style bases of the locality among higher secondary students

\begin{tabular}{|l|l|l|l|l|c|l|}
\hline Variable & Locality & Number & Mean & S.D & t value & Remarks \\
\hline $\begin{array}{l}\text { Learning } \\
\text { style }\end{array}$ & Rural & 134 & 1.36 & 0.12 & & $\begin{array}{l}\text { Not } \\
\text { significant }\end{array}$ \\
\cline { 2 - 5 } & Urban & 166 & 1.34 & 0.08 & 0.58 & \\
\hline
\end{tabular}

(at 0.05 significant level the table value of ' $t$ ' is 1.98 )

\section{Inference}

Since the calculated value (0.58) is less than the table value of ' $t$ ' (1.98), the null hypothesis is accepted. It is inferred from the above table that there is no significant difference between learning style bases of the locality among higher secondary students.

HYPOTHESIS 16: There will be a significant difference between multiple intelligence bases of the groups among higher secondary students. 
Table 19: 't' value between multiple intelligence bases of the groups among higher secondary students.

\begin{tabular}{|l|l|l|l|l|l|l|l|}
\hline Variable & Groups & Number & Mean & S.D & & $\begin{array}{c}\text { t } \\
\text { value }\end{array}$ & Remarks \\
\hline $\begin{array}{l}\text { Multiple } \\
\text { Intelligence }\end{array}$ & Science & 139 & 1.37 & 0.20 & & & $\begin{array}{l}\text { Not } \\
\text { significant }\end{array}$ \\
\cline { 2 - 6 } & Arts & 161 & 1.32 & 0.09 & & 0.42 &
\end{tabular}

(at 0.05 significant level the table value of ' $t$ ' is 1.98 )

\section{Inference}

Since the calculated value (0.42) is less than the table value of ' $t$ ' (1.98), the null hypothesis is accepted. It is inferred from the above table that there is no significant difference between multiple intelligence bases of the groups among higher secondary students.

HYPOTHESIS 17: There will be a significant difference between learning style bases of the groups among higher secondary students.

Table 20: ' $\mathrm{t}$ ' value between learning style bases of the groups among higher secondary students.

\begin{tabular}{|l|l|l|l|l|c|l|}
\hline Variable & Groups & Number & Mean & S.D & t value & Remarks \\
\hline \multirow{2}{*}{ Learning Style } & Science & 139 & 1.38 & 0.15 & 0.19 & $\begin{array}{l}\text { Not } \\
\text { significant }\end{array}$ \\
\cline { 2 - 5 } & Arts & 161 & 1.32 & 0.07 & & \\
\hline
\end{tabular}

(at 0.05 significant level the table value of ' $t$ ' is 1.98 )

\section{Inference}

Since the calculated value (0.19) is less than the table value of ' $t$ ' (1.98), the null hypothesis is accepted. It is inferred from the above table that there is no significant difference between learning style bases of the groups among higher secondary students.

HYPOTHESIS 18: There is no significant relationship between multiple intelligence and learning style of higher secondary school students

Table 21: Correlation(r) value between multiple intelligence and learning style of higher secondary school students

\begin{tabular}{|l|l|l|l|l|}
\hline S.No & Variable & N & r- value & Sig. \\
\hline 1 & Multiple intelligence & 300 & -0.380 & $\begin{array}{l}\text { Significant } \\
\text { At } 0.05 \\
\text { level }\end{array}$ \\
\hline 2 & Learning Style & & & \\
\hline
\end{tabular}

\section{Inference}

From the above table, it is noted that the calculated $\mathrm{r}$-value -0.380 is less than the tabulated $\mathrm{r}$ value 0.811 at 0.05 level. Hence the correlation is not Significant. So it cannot be confident that multiple intelligence and learning style are positively correlated in the sample of study. 


\section{Conclusion}

The purpose of the present investigation was to study "A STUDY OF MULTIPLE INTELLIGENCE IN RELATING TO LEARNING STYLE AMONG HIGHER SECONDARY STUDENTS" in relation to some selected variables. Based on the findings from the present study it was revealed that the higher mean value of female students indicates that they have higher multiple intelligence compared to their male counter part. Similarly, the higher mean value of male students indicates that they have higher learning style compared to their female counter part. When comes to locality, the higher mean value of urban area students indicates that they have higher multiple intelligence compared to rural area students. Furthermore, the higher mean value of rural area students indicates that they have higher learning style compared to urban area students. When comes to group wise, the higher mean value of Arts group students indicates that they have higher multiple intelligence compared to Science Group students. The higher mean value of Science group students indicates that they have higher learning style compared to Arts Group students. The above findings are an original contribution to the existing knowledge and no such studies have been attempted in these selected dimensions. This study might enable teachers and administrators to look for ways of enhancing multiple intelligence in relating to learning style among higher secondary school students.

\section{References}

[1] Blythe, T., \& Gardner H. (1990). A school for all intelligences. Educational Leadership. 47(7), 33-37.

[2] Fogarty, R., \& Stoehr, J. (1995). Integrating curricula with multiple intelligences. Teams, themes, and threads. K-college. Palatine, IL: IRI Skylight Publishing Inc. (ERIC Document Reproduction Service ED No. 383 435)

[3] Gardner, H. (1983). Frames of Mind. New York: Basic Book Inc.

[4] Gardner, H. (1991) The unschooled mind: how children think and how schools should teach. New York: Basic Books Inc.

[5] Gardner, H., \& Hatch, T. (1989). Multiple intelligences go to school: Educational implications of the theory of multiple intelligences. Educational Researcher, 18(8), 4-9.

[6] Kornhaber, M., \& Gardner, H. (1993, March). Varieties of excellence: identifying and assessing children's talents. A series on authentic assessment and accountability. New York: Columbia University, Teachers College, National Center for Restructuring Education, Schools, and Teaching. (ERIC Document Reproduction Service No. ED 363 396) 